\title{
木質バイオマス-合成高分子ハイブリッド材料を 基体とする陽イオン交換樹脂の合成とその特性
}

\author{
宮内 $\quad$ 俊幸 ${ }^{\circledR 1}$, 黒木 $\quad$ 和志 ${ }^{1}$, 石川 徳久 ${ }^{1}$, 高 橋 $\quad$ 誠 ${ }^{1}$, 盛 $\quad$ 秀 彦 $^{1}$
}

\begin{abstract}
ブナおが㑩をホスホン酸ジフェニルーホルムアルデヒド樹脂で化学修飾して発煙硫酸処理に耐えられる木 質バイオマス-合成高分子複合体を合成して，これを基体とするスルホン酸基を有する強酸性陽イオン交換 樹脂を得た。ブナおが屑を強化するのに必要なホスホン酸ジフェニル樹脂は原料の仕込み濃度で約 $14 \mathrm{wt} \%$ 以上あれば十分であり，原料仕込み濃度で約 $75 \mathrm{wt} \%$ ブナおが屑を基体とするスルホン酸基を有する強酸性 陽イオン交換樹脂を得ることができた．交換容量は $2.4 \mathrm{meqg}^{-1} \mathrm{-R}$ （乾燥樹脂）と良好な值であり，交換速 度も速く約 5 分以内で平衡に達し, そのため高速でのイオン交換が可能であった。密度は $1.18 \mathrm{~g} \mathrm{~mL}^{-1}$ であ り, 水溶液中で浮くという久点もなくカラム操作に十分に対応できるイオン交換樹脂であった. 本交換樹脂 は塩酸溶液あるいはメタノール-塩酸混合溶液を用いると, $\mathrm{Li}^{+}-\mathrm{K}^{+}, \mathrm{Mg}^{2+}-\mathrm{Ca}^{2+}-\mathrm{Sr}^{2+}-\mathrm{Ba}^{2+}$ の相互分離，更に は $\mathrm{Cd}^{2+}-\mathrm{Zn}^{2+}, \mathrm{Cd}^{2+}-\mathrm{Co}^{2+}$ あるいは $\mathrm{Cd}^{2+}-\mathrm{Ni}^{2+}$ などの相互分離に利用できた。
\end{abstract}

\section{1 緒言}

木質バイオマスを合成高分子で化学修飾して木質バイオ マスを主成分とする木質バイオマスー合成高分子ハイブリ ッド材料の開発とそのイオン交換体の基体としての評価を 行った。ブナ，スギ及びヒノキなどの木質廃棄物の中で一 部のおが榍はおが炭や豆炭などの燃料として，また，ボー ド類及び繊維壁剂などの改質剂として利用されているが, 大半は焼却処分されている．木質バイオマスに対する化学 的アプローチは，主にセルロース及びリグニンに対するも のであり ${ }^{1) \text { 5) }}$, 高次構造を有する木質そのものに対する研 究例は少な( ${ }^{6) ~ 8)}$. 特に木粉をイオン交換樹脂の基体とし て取り扱った研究例はない. 生体高分子である木粉はその 環境面での安全性に加えて低コストであり，付加価值を付 けて化学材料として活用することは意義のあることであ る.

木粉を合成高分子で化学修飾して補強すると耐硫酸性が 向上しスルホン酸基の導入が可能となり, 陽イオン交換樹 脂を得ることができる，木粉を基体にした交換樹脂は，従 来のスチレンージビニルベンゼン共重合体を基体とする交 換樹脂に比べて, 親水性の基体であるため, 水溶液中で金 属イオンの樹脂中への拡散が速くなり，金属イオンの相互 分離に関して新しい特性が期待される.

著者らは，これまでホスホン酸ジフェニルとホルムアル デヒドとから得られた含リンノボラック型樹脂の性質及び

\footnotetext{
${ }^{1}$ 中部大学工学部応用化学科：487-8501 愛知県春日井市松本町 1200
}

それを基体とする陽イオン交換樹脂の性質について報告し てきた ${ }^{910)}$. ホスホン酸ジフェニルはホルマリンと常温で 容易に反応してホスホン酸ジフェニルーホルムアルデヒド 樹脂を生成するが，その生成過程で生じたホスホン酸ジフ エニル樹脂の末端ヒドロキシメチル基と木質バイオマス中 のヒドロキシル基との縮合による化学結合に着目して, ホ スホン酸ジフェニル樹脂による木粉の強化を行った。

木質バイオマスとしては日本各地に豊富に生育している ブナ木の扔が屑を用い, その強化に用いるホスホン酸ジフ エニル樹脂の量は最小になることを目指し，木質バイオマ スー合成高分子複合材料を合成した。この複合体にスルホ ン酸基を導入した陽イオン交換樹脂の交換容量，吸着速 度, 密度及び酸強度などを測定し, 陽イオン交換樹脂とし ての評価を行った。また，本交換樹脂を用いて，アルカリ 金属イオン間の相互分離及びアルカリ土類金属イオン間の 相互分離，更には遷移金属イオン間の相互分離について検 討したところ，ホスホン酸ジフェニルーホルムアルデヒド 樹脂を基体とした陽イオン交換樹脂10)及び市販のスルホン 酸型陽イオン交換樹脂と比較したとき，金属イオン相互分 離に関して新しい知見を得たので報告する.

$$
2 \text { 実験 }
$$

\section{$2 \cdot 1$ 試薬及び装置}

ホスホン酸ジフェニル（DPP）は東京化成製で特に精製 せずに使用した．各種金属イオンの標準溶液は原子吸光分 析用標準溶液を使用した。脱脂ブナおが屑は東洋樹脂侏か ら提供されたものであり，それを $100 〜 150$ メッシュにそ 


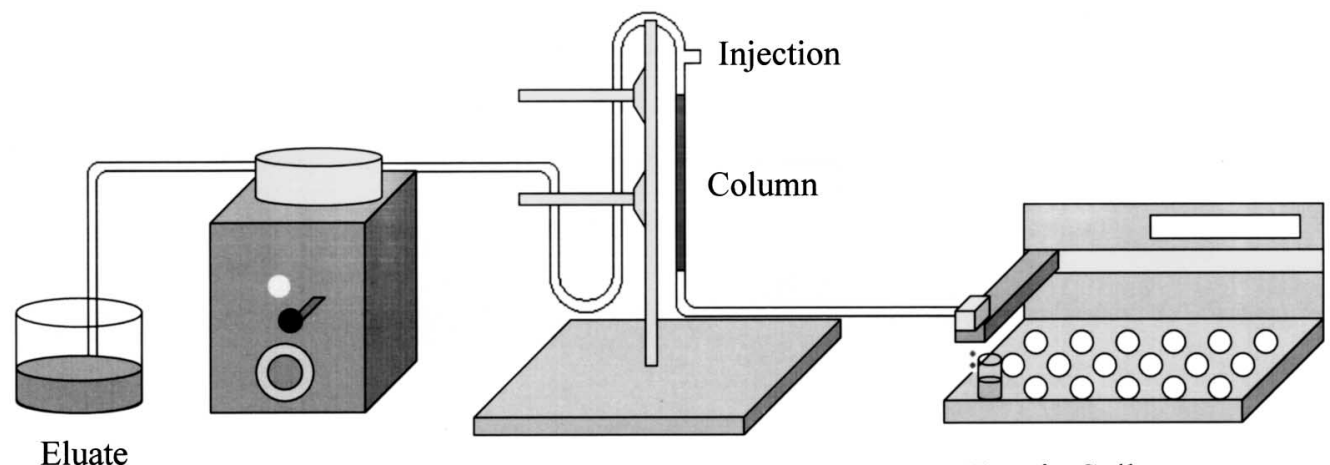

Liquid Delivery Pump

Fractio Collector

Fig. 1 Experimental apparatus for separation of metal ions

ろえて使用した。

金属イオンの測定には, エスアイアイ・ナノテクノロジ 一製誘導結合プラズマ (ICP) 発光分光分析装置 SPS7800 を使用した。合成樹脂の表面観察には，日立工機製走査型 電子顕微鏡 S-3500 を用いた. フーリエ変換赤外分光光度 計は島津製 FTIR-8300 を使用した。

\section{$2 \cdot 2$ ブナおが屑-DPP 樹脂の合成}

$500 \mathrm{~mL}$ ビーカー中で DPP $10 \mathrm{~mL}(0.04 \mathrm{~mol})$ にホルマ リン $10 \mathrm{~mL}(0.3 \mathrm{~mol})$ を加えかくはんし, 液層が均一に なったところでブナおが屑 $30 \mathrm{~g}$ をすばやく加え十分に混 合し，ブナおが屑にDPP をなじませた。続いて濃塩酸 50 $\mathrm{mL}$ を加えてかくはんし, DPP とホルムアルデヒドの縮合 反応を促進させた．約 $100{ }^{\circ} \mathrm{C}$ の湯浴上で 2 時間加熱・か くはんすると, ブナおが屑は DPP 樹脂と結合し当初の茶 色から黒色に変化した. 塩酸処理で分解したブナおが屑及 び未反応の DPPを除去するため, 水洗とアセトン洗浄を 繰り返し，ブナおが屑-DPP 樹脂を回収した（粗収量 $38 \mathrm{~g})$. 以下, DPP の量を $5,2.5,1 \mathrm{~mL}$ と変え同様の操 作を行ってブナおが屑-DPP 樹脂を得た.

\section{$\mathbf{2 \cdot 3}$ ブナおが屑-DPP 樹脂のスルホン化}

ブナおが屑-DPP 樹脂 $38 \mathrm{~g}$ を $500 \mathrm{~mL}$ ビーカーに入れ, 濃硫酸 $100 \mathrm{~mL}$ を加えて 20 分間浸漬した。続いて発煙硫 酸 $30 \mathrm{~mL}$ を加えてかくはんした. 40 分後に水中に注ぎ, 水洗後アセトンで洗浄し, 続いて水酸化ナトリウム水溶液 及び塩酸水溶液で洗浄した。水洗を十分に繰り返し, $100{ }^{\circ} \mathrm{C}$ で乾燥した。発煙硫酸処理でブナおが屑-DPP 樹脂 は約 $26 \%$ 減少したが，スルホン化樹脂の粗収量は約 $24 \mathrm{~g}$ であり，十分満足すべき収量となった。以下，ブナおが屑 と DPP との仕込み量を変えて得たブナおが屑-DPP 樹脂 のスルホン化樹脂を SB-DPP と略記する.

\section{$2 \cdot 4$ 交換容量の測定}

SB-DPP $1 \mathrm{~g}$ をひょう取し, 内径 $8 \mathrm{~mm}$, 長さ $250 \mathrm{~mm}$ の カラムに水を用いて移し, $1.0 \mathrm{~mol} \mathrm{~L}^{-1}$ 塩酸水溶液を $4 \mathrm{~mL} \mathrm{~min}{ }^{-1}$ で $200 \mathrm{~mL}$ 通液した. 次に純水で洗浄した後, $5 \mathrm{wt} \%$ 硫酸銅水溶液を $100 \mathrm{~mL}$ 通液した. 純水で洗浄した 後, $1.0 \mathrm{~mol} \mathrm{~L}^{-1}$ 塩酸水溶液 $50 \mathrm{~mL}$ を通液し, $\mathrm{Cu}^{2+}$ を溶出 して全量を $100 \mathrm{~mL}$ にした. $\mathrm{Cu}^{2+}$ 濃度を測定し，交換容量 を求めた。

\section{$2 \cdot 5$ 金属イオンの相互分離}

金属イオンの相互分離に使用した装置を Fig. 1 に示し た.内径 $8 \mathrm{~mm}$, 長さ $250 \mathrm{~mm}$ のシリコーン製チューブカ ラムに SB-DPP $2 \mathrm{~g}$ を詰め, 移動相に $0.1 \sim 0.5 \mathrm{~mol} \mathrm{~L}^{-1}$ 塩 酸を用いて流量 $2 \mathrm{~mL} \mathrm{~min}^{-1}$ で展開した。 サンプル注入口

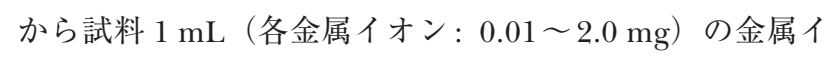
オンをマイクロシリンジで注入した。溶出液 $10 \mathrm{~mL} 5$ 分間隔でフラクションコレクターで採取した.

\section{$2 \cdot 6$ 見掛け密度の測定}

見掛け密度の測定にはピクノメーターを用いて次式によ り求めた。

$$
d=\frac{\left(W_{\mathrm{b}}-W_{\mathrm{a}}\right) d_{\mathrm{w}}}{W_{\mathrm{b}}+W_{\mathrm{d}}-W_{\mathrm{a}}-W_{\mathrm{c}}}
$$

ただし， $W_{\mathrm{a}}$ : ピクノメーターの重さ， $W_{\mathrm{b}}$ : ピクノメー ター+ SB-DPP の重さ, $W_{\mathrm{c}}$ : ピクノメーター + SB-DPP + 水の重さ, $W_{\mathrm{d}}$ : ピクノメーター+水の重さ, $d_{\mathrm{w}}: 25^{\circ} \mathrm{C}$ で の水の密度である.

\section{3 結果と考察}

\section{$3 \cdot 1$ SB-DPP の性質}

ブナおが屑の化学修飾には木質中のヒドロキシル基と結 
Table 1 Synthesis and properties of SB-DPP

\begin{tabular}{|c|c|c|c|c|c|c|}
\hline \multicolumn{2}{|c|}{$\begin{array}{c}\text { Nominal } \\
\text { amount }\end{array}$} & \multirow{2}{*}{$\begin{array}{c}\text { Nominal } \\
\text { fraction }^{\text {b) }} / \\
\text { wt } \%\end{array}$} & \multirow{2}{*}{$\begin{array}{c}\text { Amount of beech } \\
\text { sawdust-DPP resin/ } \\
\mathrm{g}\end{array}$} & \multirow{2}{*}{$\begin{array}{c}\text { Amount of } \\
\text { SB-DPP }^{c} / \\
\text { g }\end{array}$} & \multirow{2}{*}{$\begin{array}{l}\text { Exchange } \\
\text { capacity/ } \\
\text { meq g }^{-1}\end{array}$} & \multirow{2}{*}{$\begin{array}{c}\text { Apparent } \\
\text { density/ } \\
\mathrm{g} \mathrm{mL}^{-1}\end{array}$} \\
\hline Beech & $\mathrm{DPP}^{\mathrm{a})} /$ & & & & & \\
\hline 30 & 10 & 75 & 38 & 24 & 2.4 & 1.18 \\
\hline 30 & 5 & 86 & 30 & 21 & 2.0 & 1.17 \\
\hline 30 & 2.5 & 92 & 16 & 10 & 0.6 & 1.12 \\
\hline 30 & 1 & 97 & 10 & 5 & 0.4 & 1.10 \\
\hline
\end{tabular}

a) Diphenylphosphonate; b) Beech/(beech + DPP); c) Sulufonated beech- diphenylphosphonate formaldehyde resin
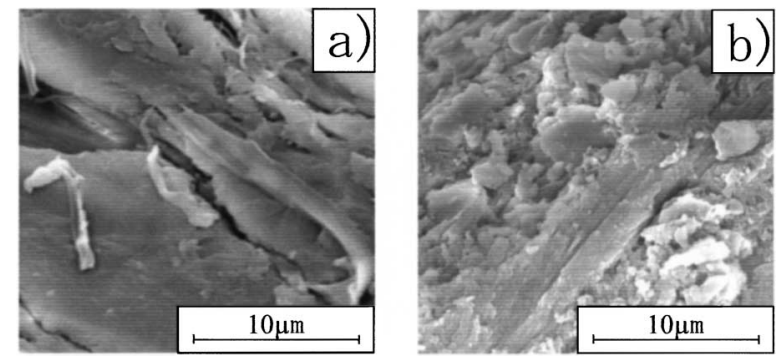

Fig. 2 SEM picture of beech sawdust and beech sawdust-DPP resin

a) Beech sawdust; b) 75 wt $\%$ Beech sawdust-DPP resin

合しやすいフェノール-ホルムアルデヒデド樹脂及び DPP - ホルムアルデヒド樹脂を用いた。フェノールーホル ムアルデヒド樹脂で処理したときブナおが屑 $30 \mathrm{~g}$ に対し て,ブナおが屑ーフェノール樹脂の粗収量は約 $10 \mathrm{~g}$ となり, DPP - ホルムアルデヒド樹脂で処理したときの約 4 分の 1 であった。また，スルホン化するとその粗収量は著しく減 少し (約 $5 \mathrm{~g}$ ), その交換容量も $0.4 \mathrm{meq} \mathrm{g}^{-1}-\mathrm{R}$ (乾燥樹脂) と低い值であった。これに対して, DPP-ホルムアルデヒ ド樹脂で処理するとブナおが屑-DPP 樹脂及びそのスルホ ン化樹脂の粗収量は高く, ブナおが屑の化学修飾には DPP - ホルムアルデヒド樹脂が最適であった.

ブナおが屑 $30 \mathrm{~g}$ に対して DPP 量を変えてブナおが屑の 化学修飾を行い, 両物質の仕込み量におけるブナおが屑一 DPP 樹脂の粗収量を Table 1 に示した。仕込み比でブナ の量が約 $92 \mathrm{wt} \%$ 以上になると, ブナおが屑-DPP 樹脂の 粗収量は低下するが, 約 $86 \mathrm{wt} \%$ 以下の仕込み量では粗収 量は高い值となった。次にブナおが屑-DPP 樹脂を発煙硫 酸で処理してスルホン酸基を導入したが，仕达み量で約 $86 \mathrm{wt} \%$ 以下のブナおが屑では粗収量は良好であり，また， その交換容量も $2.0 \mathrm{meq} \mathrm{g}^{-1}-\mathrm{R}$ 以上となり（Table 1), 市 販の交換樹脂の交換容量にほぼ匹敵する值であった。以 降，原料仕込み量で $75 \mathrm{wt} \%$ ブナおが屑（仕込み量 25 $\mathrm{wt} \%$ DPP 樹脂）を基体とする陽イオン交換樹脂を対象に してその物性評価と金属イオン選択性について検討した。 木粉を化学材料として取り扱う上での欠点は水に浮くこと

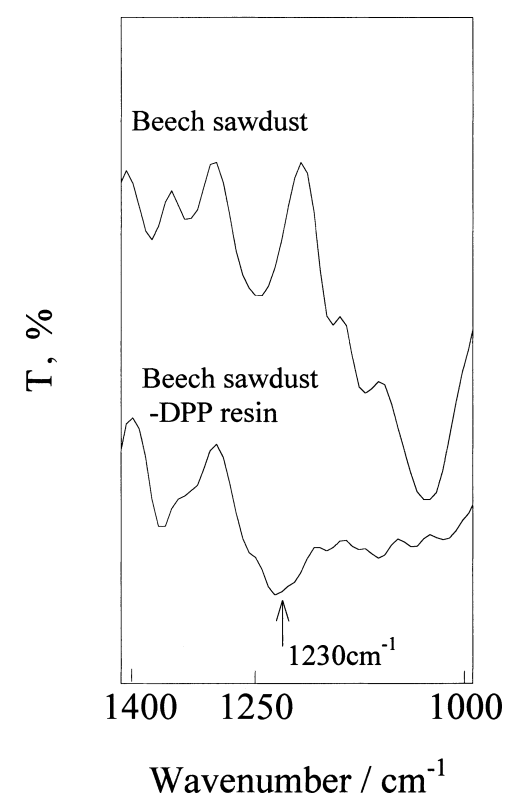

Fig. 3 FT-IR spectra of beech sawdust and $75 \mathrm{wt} \%$ beech sawdust-DPP resin

である。そこで SB-DPP 樹脂の密度を測定した（Table 1) が，密度は約 $1.10 \sim 1.18 \mathrm{~g} \mathrm{~mL}^{-1}$ の範囲にあり，水中での 取り扱いに支障はなかった。

ブナおが屑と SB-DPP の走査電子顕微鏡写真を Fig. 2 に 示した。ブナおが屑の表面は均一であるが，DPP 樹脂で 処理したブナおが屑の表面は粗くなっており，これはブナ おが屑の表面が DPP 樹脂でコーティングされていること を示している.ブナおが屑と DPP 樹脂の結合は，ブナお が屑のセルロース中のヒドロキシル基と DPP 樹脂の末端 にあるヒドロキシメチル基との脱水縮合によるものと推定 している. 両者の赤外吸収スペクトルを Fig. 3 に示した. SB-DPP では $1230 \mathrm{~cm}^{-1}$ にエーテル結合の逆対称伸縮に基 づく吸収帯が観測される。これは脂肪族エーテルの逆対称 伸縮 $\left(1125 \mathrm{~cm}^{-1}\right)$ より高波数側にあり，また，アリール アルキルエーテルの逆対称伸縮 $\left(1275 \mathrm{~cm}^{-1}\right)$ よりは低波 数側にあり, DPP 中のベンゼン環に付いた末端ヒドロキ シメチル基とセルロース中のヒドロキシル基との結合によ 


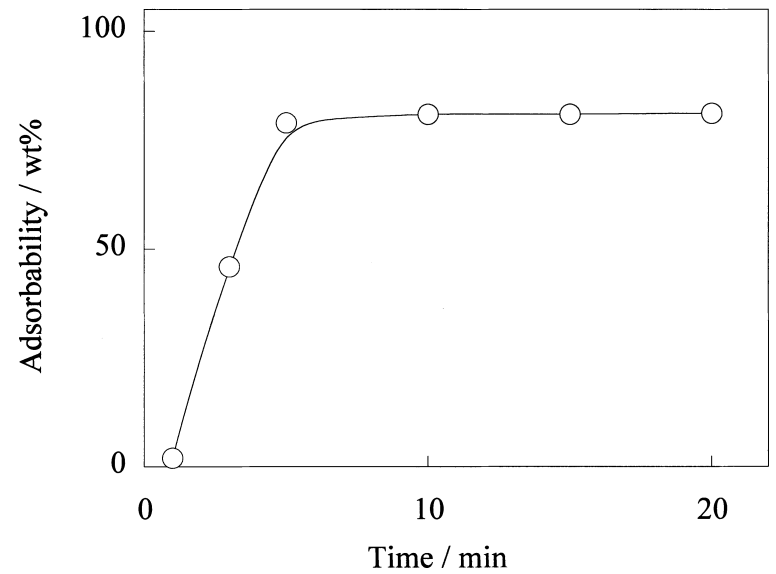

Fig. 4 Time dependence of $\mathrm{Cu}^{2+}$ adsorption on SBDPP

$75 \mathrm{wt} \%$ SB-DPP: $1.0 \mathrm{~g}$; pH: 3.2; Concentration of $\mathrm{Cu}^{2+}: 10 \mathrm{mg} \mathrm{L}^{-1}$; Temp.: $25 \pm 1^{\circ} \mathrm{C}$

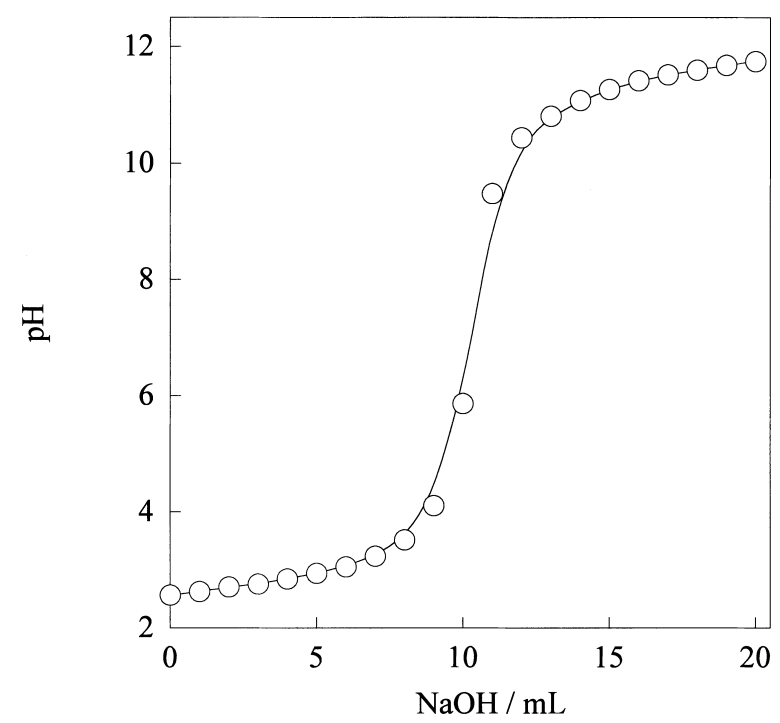

Fig. $5 \mathrm{pH}$ titration curves of SB-DPP in water $75 \mathrm{wt} \%$ SB-DPP : $1.0 \mathrm{~g}$; Titrant: $0.2 \mathrm{~mol} \mathrm{~L}^{-1} \mathrm{NaOH}$; Temp. : $25 \pm 1^{\circ} \mathrm{C}$

って生じたエーテル結合の吸収帯と考えている.

$\mathrm{Cu}^{2+}$ イオンを用いて SB-DPP の吸着速度を測定した (Fig. 4). 約 5 分で吸着平衡に達しており, カラム操作に よるイオン交換に十分に対応できことを示している．しか も通液性に優れているので, 高速でのイオン交換が可能で あった。すなわち, 内径 $8 \mathrm{~mm}$, 長さ $250 \mathrm{~mm}$ のカラムに SB-DPPを $2 \mathrm{~g}$ 充填し, $1 \mathrm{mg} \mathrm{mL} \mathrm{mL}^{-1}$ の $\mathrm{Cu}^{2+}$ イオンを 10 $\mathrm{mL} \min ^{-1}$ の高速で展開しても $\mathrm{Cu}^{2+}$ イオンの漏出は認めら れなかった。

SB-DPP の $\mathrm{pH}$ 滴定曲線を Fig. 5 に示した. 滴定曲線の 形状から判断して SB-DPP は強酸性型の陽イオン交換樹脂
Table 2 Decrease in exchange capacity on repeated runs of SB-DPP

\begin{tabular}{cc}
\hline Run & $\begin{array}{c}\text { Exchange capacity/ } \\
\left(\text { meq g }^{-1}\right)\end{array}$ \\
\hline 1 & 2.4 \\
3 & 2.4 \\
5 & 2.4 \\
7 & 1.8 \\
9 & 1.4 \\
\hline
\end{tabular}

Column : $8 \phi \times 250 \mathrm{~mm} ; 75 \mathrm{wt} \%$ SB-DPP : $2.0 \mathrm{~g} ; \mathrm{pH}$ of $\mathrm{Cu}^{2+}$ solution: 3.2 ; Flow rate of $\mathrm{Cu}^{2+}$ solution : $5 \mathrm{~mL} \mathrm{~min}^{-1}$

Table 3 Distribution coefficients of metal ions in various concentration of hydrochloric acid

\begin{tabular}{lrcc}
\hline & \multicolumn{3}{c}{ Concentration of $\mathrm{HCl} / \mathrm{mol} \mathrm{L}^{-1}$} \\
\cline { 2 - 4 } Cation & 0.1 & 0.25 & 0.5 \\
\hline $\mathrm{Li}^{+}$ & 10 & 0 & 0 \\
$\mathrm{Na}^{+}$ & 10 & 0 & 0 \\
$\mathrm{~K}^{+}$ & 40 & 10 & 0 \\
$\mathrm{Mg}^{2+}$ & 290 & 30 & 0 \\
$\mathrm{Ca}^{2+}$ & 500 & 20 & 0 \\
$\mathrm{Sr}^{2+}$ & 680 & 180 & 70 \\
$\mathrm{Ba}^{2+}$ & 9800 & 520 & 140 \\
$\mathrm{Mn}^{2+}$ & 1800 & 540 & 100 \\
$\mathrm{Co}^{2+}$ & 910 & 80 & 30 \\
$\mathrm{Ni}^{2+}$ & 600 & 20 & 0 \\
$\mathrm{Zn}^{2+}$ & 830 & 60 & 20 \\
$\mathrm{Cu}^{2+}$ & 130 & 60 & 10 \\
$\mathrm{Cd}^{2+}$ & 240 & 0 & 0 \\
$\mathrm{Cr}^{3+}$ & 1800 & 540 & 100 \\
$\mathrm{Fe}^{3+}$ & 810 & 70 & 30 \\
$\mathrm{Al}^{3+}$ & 1150 & 230 & 80 \\
\hline
\end{tabular}

に相当する．水酸化ナトリウム消費量から算出した水素イ オン濃度は約 $1.9 \mathrm{meq} \mathrm{g}^{-1}-\mathrm{R}$ (乾燥樹脂) で SB-DPP の交 換容量とほぼ一致している. カラム操作での SB-DPP の再 生利用について検討した (Table 2).5 回の再生使用まで は交換容量の減少が認められなかった。 $0.1 〜 0.5 \mathrm{~mol} \mathrm{~L}^{-1}$ 塩酸溶液中で種々の金属イオンの分布係数值を求め, Table 3 に示した. $0.5 \mathrm{~mol} \mathrm{~L}^{-1}$ 塩酸溶液で対象とした金属 イオンの分布係数值は 0 〜 150 の範囲にあった。この值は 同じ条件下で求めた市販のスルホン酸型陽イオン交換樹脂 (DAIION SK 1B）の分布係数（80～750） と比較して非常 に低い值であり，0.5 mol L ${ }^{-1}$ 塩酸溶液を用いると対象と した金属イオン間の相互分離ができることを示している.

\section{$3 \cdot 2$ 金属イオンの相互分離}

実験操作 $2 \cdot 5$ に示した金属イオン分離システムで 0.5 $\mathrm{mol} \mathrm{L}^{-1}$ 塩酸溶液を通液しながら試料注入口からアルカリ 金属イオン及び $\mathrm{Mg}^{2+}$ とアルカリ土類金属イオンを同量含 む試料を入れ，展開した。その溶出曲線を Fig. 6 に示し た.この条件下では, $\mathrm{Li}^{+}, \mathrm{Na}^{+}$及び $\mathrm{K}^{+}$は共に溶出し分離 


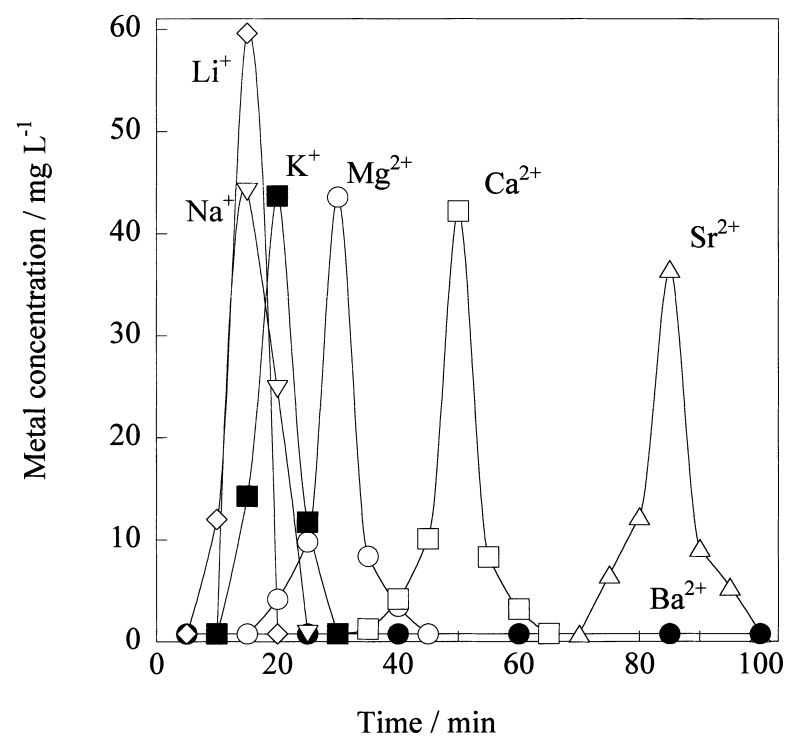

Fig. 6 Elution curves for alkaline metal, $\mathrm{Mg}^{2+}$, and alkaline earth metal ions

Column : $8 \phi \times 250 \mathrm{~mm}$; $75 \mathrm{wt} \%$ SB-DPP : $2.0 \mathrm{~g}$; Eluent: $0.5 \mathrm{~mol} \mathrm{~L}^{-1}$ hydrochloric acid; Flow rate : $2 \mathrm{~mL} \mathrm{~min}^{-1}$

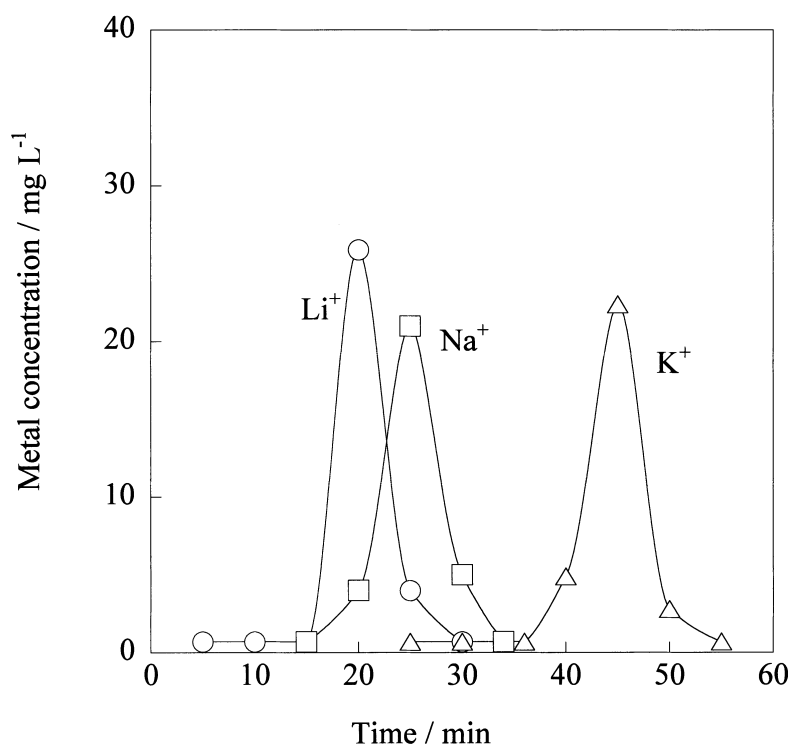

Fig. 7 Elution curves for alkaline metal ions

Column : $8 \phi \times 250 \mathrm{~mm}$; $75 \mathrm{wt} \%$ SB-DPP : $2.0 \mathrm{~g}$; Eluent: 20\% methanol-0.15 mol L ${ }^{-1}$ hydrochloric acid; Flow rate: $2 \mathrm{~mL} \mathrm{~min}^{-1}$

できないが，塩酸濃度を下げると $\mathrm{Li}^{+} \rightarrow \mathrm{Na}^{+} \rightarrow \mathrm{K}^{+}$の順に分 離溶出する傾向が見られ，20\%メタノール $-0.15 \mathrm{~mol} \mathrm{~L}^{-1}$ 塩酸混合溶液を用いると $\mathrm{Li}^{+}$と $\mathrm{K}^{+}$は完全に分離できた (Fig. 7).

$\mathrm{Ba}^{2+}$ はカラム内に保持されたままであるが, $\mathrm{Mg}^{2+}$ と $\mathrm{Ca}^{2+}$ 及び $\mathrm{Sr}^{2+}$ は溶出した. $\mathrm{Mg}^{2+}$ と $\mathrm{Ca}^{2+}$ の溶出曲線は一部 重なり合うが, $\mathrm{Sr}^{2+}$ とは完全に分離している. $\mathrm{Ba}^{2+}$ は 2.0

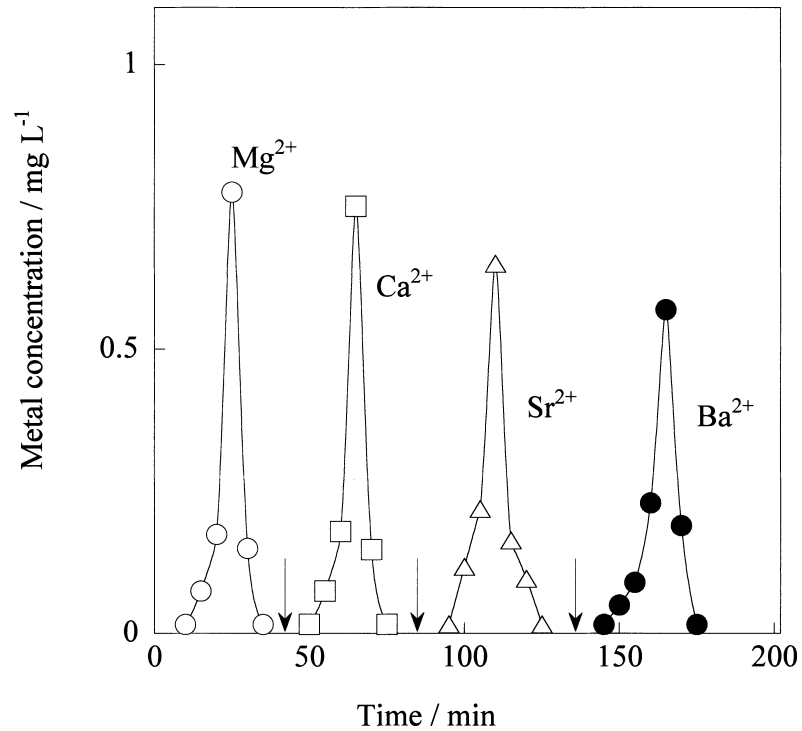

Fig. 8 Elution curves for $\mathrm{Mg}^{2+}, \mathrm{Ca}^{2+}, \mathrm{Sr}^{2+}$ and $\mathrm{Ba}^{2+}$ Column : $8 \phi \times 250 \mathrm{~mm}$; $75 \mathrm{wt} \%$ SB-DPP : $2.0 \mathrm{~g} ; \downarrow$ : change of eluent; Eluent- $\mathrm{Mg}^{2+}: 20 \%$ methanol- 0.25 mol L ${ }^{-1}$ hydrochloric acid; $\mathrm{Ca}^{2+}$ and $\mathrm{Sr}^{2+}: 0.5 \mathrm{~mol} \mathrm{~L}{ }^{-1}$ hydrochloric acid; $\mathrm{Ba}^{2+}: 2.0 \mathrm{~mol} \mathrm{~L}{ }^{-1}$ hydrochloric acid; Flow rate: $2 \mathrm{~mL} \mathrm{~min}^{-1}$

$\mathrm{mol} \mathrm{L}{ }^{-1}$ 塩酸溶液を用いると溶出できるので, $\mathrm{Mg}^{2+}-\mathrm{Sr}^{2+}$ $\mathrm{Ba}^{2+}$ 及び $\mathrm{Ca}^{2+}-\mathrm{Sr}^{2+}-\mathrm{Ba}^{2+}$ の三元分離が可能となる。分離が 不完全な $\mathrm{Mg}^{2+}$ と $\mathrm{Ca}^{2+}$ についてメタノール-塩酸混合溶液 で展開して分離の度合いを調べた。 $20 \%$ メノール -0.25 $\mathrm{mol} \mathrm{L}{ }^{-1}$ 塩酸溶液を用いると, $\mathrm{Mg}^{2+}$ のみが溶出し $\mathrm{Ca}^{2+}$ と 分離できた。そこで $20 \%$ メタール $-0.25 \mathrm{~mol} \mathrm{~L}^{-1}$ 塩酸 溶液, $0.5 \mathrm{~mol} \mathrm{~L}^{-1}$ 塩酸溶液及び $2.0 \mathrm{~mol} \mathrm{~L}^{-1}$ 塩酸溶液を順 に展開すると, $\mathrm{Mg}^{2+}, \mathrm{Ca}^{2+}, \mathrm{Sr}^{2+}$ 及び $\mathrm{Ba}^{2+}$ をうまく相互 に分離することができた（Fig. 8).

次に 2 価金属イオン, $\mathrm{Co}^{2+}, \mathrm{Ni}^{2+}, \mathrm{Cu}^{2+}, \mathrm{Zn}^{2+}$ 及び $\mathrm{Cd}^{2+}$ と 3 価金属イオン, $\mathrm{Al}^{3+}, \mathrm{Cr}^{3+}$ 及び $\mathrm{Fe}^{3+}$ について 0.5 $\mathrm{mol} \mathrm{L}^{-1}$ 塩酸溶液で展開し，相互に分離ができた金属イオ ン間の溶出曲線を Fig. 9 に示した. $\mathrm{Cd}^{2+}$ と $\mathrm{Zn}^{2+}$ とはその 溶出曲線が一部重なり合い完全な分離ではないが, $\mathrm{Cd}^{2+}$ と $\mathrm{Co}^{2+}$ あるいは $\mathrm{Ni}^{2+}$ とは完全に分離し，また， $\mathrm{Zn}^{2+}$ 及び $\mathrm{Cu}^{2+}$ は共に $\mathrm{Co}^{2+}$ あるいは $\mathrm{Ni}^{2+}$ からそれぞれ分離できた。 $\mathrm{Fe}^{3+}$ は $\mathrm{Al}^{3+}$ 及び $\mathrm{Cr}^{3+}$ とから分離でき, カラムに保持され ている $\mathrm{Al}^{3+}$ と $\mathrm{Cr}^{3+}$ は $2.0 \mathrm{~mol} \mathrm{~L}^{-1}$ 塩酸溶液で同時に溶出し た。溶出曲線が一部重なり合う $\mathrm{Cd}^{2+}$ と $\mathrm{Zn}^{2+}$ は $20 \%$ メ夕 ノール $-0.25 \mathrm{~mol} \mathrm{~L}^{-1}$ 塩酸溶液で展開すると完全に分離で きた（Fig. 10）.

これまで金属イオンの相互分離には，キレート樹脂や弱 酸性型陽イオン交換樹脂が多用されており，スルホン酸型 陽イオン交換樹脂を用いた報告はない ${ }^{11) ~ 16)}$ 。また，DPP 樹脂を基体としたスルホン酸型陽イオン交換樹脂 ${ }^{10)}$ では, 


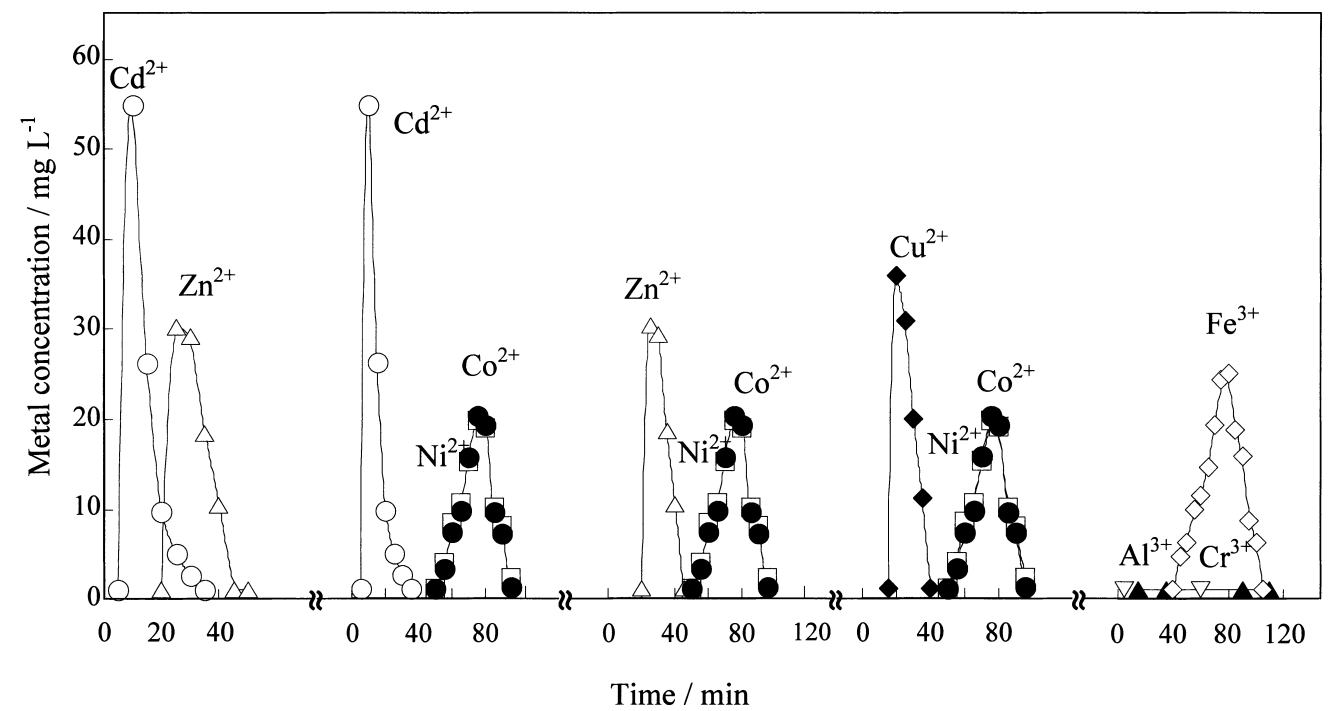

Fig. 9 Elution curves for transition metal ions

Column : $8 \phi \times 250 \mathrm{~mm}$; $75 \mathrm{wt} \%$ SB-DPP : $2.0 \mathrm{~g}$; Eluent: $0.5 \mathrm{~mol} \mathrm{~L}{ }^{-1}$ hydrochloric acid ; Flow rate: $2 \mathrm{~mL} \mathrm{~min}^{-1}$

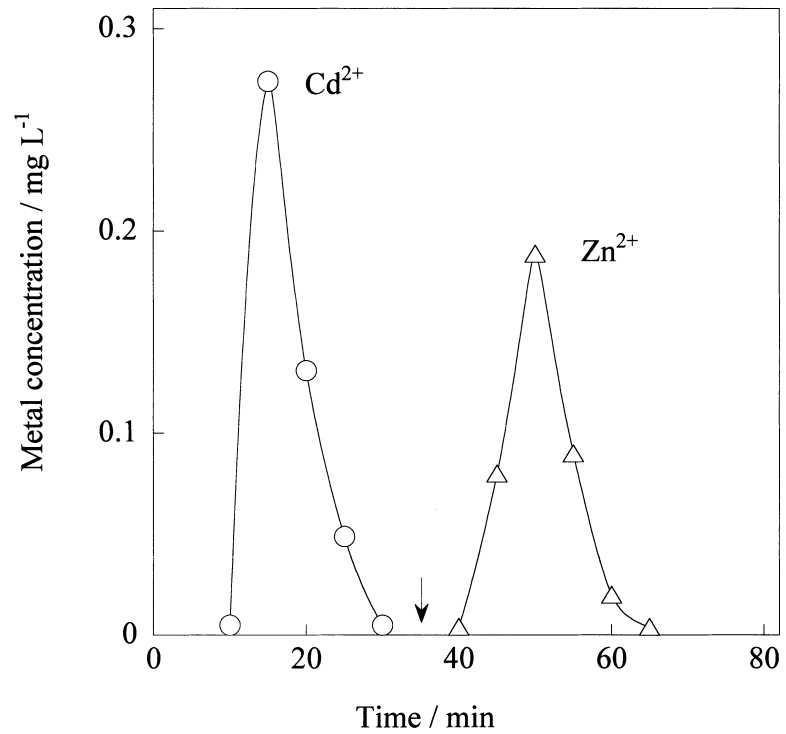

Fig. 10 Elution curves for $\mathrm{Cd}^{2+}$ and $\mathrm{Zn}^{2+}$

Column : $8 \phi \times 250 \mathrm{~mm}$; $75 \mathrm{wt} \%$ SB-DPP : $2.0 \mathrm{~g} ; \downarrow$ : change of eluent; Eluent- $\mathrm{Cd}^{2+}: 20 \%$ methanol- 0.25 mol L ${ }^{-1}$; hydrochloric acid; $\mathrm{Zn}^{2+}: 0.5 \mathrm{~mol} \mathrm{~L}^{-1}$ hydrochloric acid; Flow rate: $2 \mathrm{~mL} \mathrm{~min}^{-1}$

相互分離に対して多量の溶離液を要し，その結果，分離に 長時間を要する欠点があったが，SB-DPPを用いると希塩 酸溶液あるいはそのメ夕ノールとの混合溶液で比較的短時 間で相互分離できる特性が見いだされた。これは木質の有 する高次構造と親水性の性質が金属イオンの相互分離に寄 与したものと推測している.
4 結 言

大半が廃棄されているブナおが屑を合成高分子で化学修 飾することによって，おが屑の化学材料としての活用を試 みた。その活用の一環としてこれを基体とする陽イオン交 換樹脂を合成してその評価を行った。おが屑の強化に用い る合成高分子の量を最小にすることで，交換樹脂の使用に 際して，環境面での安全性の確保と経済面での低コストを 目指した．交換容量，交換速度及び通液性などに優れ，ま た，金属イオン分離に関しては木質の有する高次構造及び その親水性に基づく特性が見いだされた。市販のイオン交 換樹脂の基体であるスチレン-ジビニルベンゼン共重合体 に比べて非常に安価であるので，大量使用ができる利点が ある。例えば，工業的用途として河川水中の金属イオンの 除去・回収あるいは工業用の純水製造などに適用できると 考えられる。

\section{文献}

1) A. Hebeish, A. Waly, F. A. Abdel-Mohdy, A. S. Aly: J. Appl. Polym. Sci., 66, 1029 (1997).

2) A. Hebeish, Z. H. El-Hilw: J. Appl. Polym. Sci., 67, 739 (1998).

3) M. H. V. Baouab, R. Gauthier, B. Chabert, M. B. Ramnah: J. Appl. Polym. Sci., 77, 171 (2000).

4) M. Yu, W. Tian, D. Sun, W. Shan, G. Wang, N. Xu: Anal. Chim. Acta, 428, 209 (2001).

5) S. Sana, B. Sibel: 18th Annual International Ion Chromatography Symposium, September 18-21 (2005).

6) T. O. Odozi, S. Okeke, R. B. Lartey: Agric Wastes, 12 , 13 (1985).

7) C. Raji, T. S. Anirudhan: Indian J. Chem. Technol., 3, No. 6, 345 (1996). 
8) M. Geay, V. Marchetti, B. Loubinoux, P. Gerardin, A. Clenent: J. Wood Sci., 46, 331 (2000).

9) H. Mori, Y. Fujimura, Y. Takegami: Bull. Chem. Soc. Jpn., 54, 927 (1981).

10) 盛 秀彦, 藤村義和, 武上喜信：日本化学会誌, $1980,338$.

11) J. Das, N. Das: J. Indian. Chem. Soc., 66, 724 (1989).

12) M. H. H. Mahmoud, M. Kanesato, T. Yokoyama, T.
M. Suzuki: Anal. Sci., 10, 929 (1994).

13) N. V. Jarvis, J. M. Wagener: Talanta, 41, 747 (1994).

14) H. Lu, Y. Hou, F. Liu, K. Li, S. Tong: J. Liq. Chromatogr. Realat. Technol., 20, 3173 (1997).

15) R. Kadnar: J. Chromatogr., 807, 217 (1998).

16) W. Hu, K. Hasebe, K. Tanaka, J. S. Fritz: J. Chromatogr. A, 956, 139 (2002).

\title{
Preparation and Characterization of Cation Exchanger Based on \\ Woody Biomass Modified by Synthetic polymer
}

\author{
Toshiyuki Mryauchi ${ }^{1}$, Kazushi Kuroki ${ }^{1}$, Norihisa Ishikawa ${ }^{1}$, \\ Makoto TAKAHASHI ${ }^{1}$ and Hidehiko MORI ${ }^{1}$ \\ ${ }^{1}$ Department of Applied Chemistry, College of Engineering, Chubu University, 1200, Matumoto-cho, Kasugai- \\ shi, Aichi 487-8501
}

(Received 31 July 2006, Accepted 5 October 2006)

A chemical modification of beech sawdust with diphenylphosphonate- formaldehyde resin was applied to prepare a woody biomass-synthetic polymer hybrid material able to resist a fuming sulfuric acid treatment. The amount of diphenylphosphonate -formaldehyde resin required to reinforce beech sawdust was more than about $14 \mathrm{wt} \%$ for a nominal concentration of materials. Thus, a cation exchanger based on about $75 \mathrm{wt} \%$ beech sawdust for a nominal concentration of materials was prepared. The ion-exchange capacity was $2.4 \mathrm{meq} \mathrm{g}^{-1}-\mathrm{R}$ (dry exchanger). The rate of adsorption was rapid, and the adsorption equilibrium was attained within about 5 min. Thus, the ion exchanger permitted a high flow rate due to the coarse shape. Because for density of the ion exchanger was $1.18 \mathrm{~g} \mathrm{~mL}^{-1}$, the ion exchanger resin did not float in the water, and was able to be applied to the column operation. By using hydrochloric acid or methanolhydrochloric acid, the ion exchanger could be utilized for the mutual separation of $\mathrm{L}^{+}-\mathrm{K}^{+}$, $\mathrm{Mg}^{2+}-\mathrm{Ca}^{2+}-\mathrm{Sr}^{2+}-\mathrm{Ba}^{2+}$, and transition metal ions, such as $\mathrm{Cd}^{2+}-\mathrm{Zn}^{2+}, \mathrm{Cd}^{2+}-\mathrm{Co}^{2+}$, and $\mathrm{Cd}^{2+}-\mathrm{Ni}^{2+}$.

Keywords : beech sawdust; diphenylphosphonate; cation exchanger; metal separation. 